\title{
The brown algae Saccharina japonica and Sargassum horneri exhibit species-specific responses to synergistic stress of ocean acidification
} and eutrophication

\author{
LIU Yuxin ${ }^{1)}$, CAO Jiazhen ${ }^{1)}$, CHU Yaoyao ${ }^{1)}$, LIU Yan ${ }^{1), 2)}$, WANG Qiaohan ${ }^{1), 2)}$, \\ GONG Qingli $^{1), 2)}$, and LI Jingyu ${ }^{1), 2) *}$ \\ 1) Fisheries College, Ocean University of China, Qingdao 266003, China \\ 2) Key Laboratory of Mariculture, Ministry of Education, Ocean University of China, Qingdao \\ 266003, China
}

\begin{abstract}
Ocean acidification and eutrophication are two important environmental stressors. They inevitably impact marine macroalgae, and hence the coastal ecosystem of China. Saccharina japonica, as the main culture species in China, is suffering the harmful golden tide caused by Sargassum horneri. However, it remains unclear whether the detrimental effects of $S$. horneri on S. japonica cultivation become more severe in future acidified and eutrophic scenario. In this study, we respectively investigated the effects of $\mathrm{pCO}_{2}(400 \mu \mathrm{atm}$ and $1000 \mu \mathrm{atm})$ and nutrients (non-enriched and enriched seawater) on the growth, photosynthesis, respiration, chlorophyll contents, and tissue nitrogen of S. japonica and S. horneri. Results indicated that enrichment of nutrients contributed $S$. horneri to utilize $\mathrm{HCO}_{3}{ }^{-}$. The carbon acquisition pathway shifted from $\mathrm{HCO}_{3}^{-}$to $\mathrm{CO}_{2}$ in $S$. japonica, while $S$. horneri remained using $\mathrm{HCO}_{3}{ }^{-}$regulated by nutrient enrichment. S. horneri exhibited better photosynthetic traits than S. japonica, with a higher level of net photosynthetic rate and chlorophyll contents at elevated $p \mathrm{CO}_{2}$ and enriched nutrients. Tissue nitrogen also accumulated richly in the thalli of $S$. horneri under higher $p \mathrm{CO}_{2}$ and nutrients. Significant enhancement in growth was only detected in S. horneri under synergistic

\footnotetext{
* Corresponding author. Tel: 0086-532-82032377

E-mail: qdlijingyu@ouc.edu.cn
} 
stress. Together, S. horneri showed competitive dominance in current study. These findings suggest that increasing risk of golden tide in acidified and eutrophic ocean can most likely result in great damage to $S$. japonica cultivation.

Keywords Eutrophication, Ocean acidification, Saccharina japonica, Sargassum horneri, Synergistic stress

\section{Introduction}

The concentration of atmospheric carbon dioxide $\left(\mathrm{CO}_{2}\right)$ increased approximately 130 pars per million (ppm) since the Industrial Revolution (Joos \& Spahni, 2008; AOAN, 2019). Rising atmospheric $\mathrm{CO}_{2}$ dissolve in seawater, causing $\mathrm{pH}$ reductions and alterations in chemical balances of dissolved inorganic carbon (DIC) (Feely et al., 2004, 2009; Doney et al., 2009). These changes in pH and DIC are ineluctable consequences of rising atmospheric $\mathrm{CO}_{2}$, referred to as ocean acidification (OA) (Doney et al., 2009). Anthropogenic $\mathrm{CO}_{2}$ emission is rising at the fastest rate after the Industrial Era (Joos \& Spahni, 2008; AOAN, 2019), thus leading to a continuing decrease in seawater pH (Feely et al., 2004, 2009; Doney et al., 2009; Feely, Doney \& Cooley, 2009). OA significantly affects the physiological processes and ecological functions of seaweeds and other marine organisms (Gazeau et al., 2007; Edmunds, 2011; Koch et al., 2013; Kroeker et al., 2013; Enochs et al., 2015; Gao et al., 2019). Previous studies showed that photosynthetic organisms including macroalgae appear to benefit from elevated $\mathrm{CO}_{2}$ and tolerant to declined $\mathrm{pH}$ (Shi et al., 2012, 2019; Britton et al., 2016; Gao et al., 2019). A body of evidence indicates that OA actively stimulates the growth of kelps, such as Saccharina latissima, Ulva rigida and Macrocystis pyrifera which were carbon limited in nearshore environment (Swanson \& Fox, 2007; Xu et al., 2019; Hurd et al., 2020; Zhang et al., 2020). On the other hand, OA simultaneously reduces the calcification of Marginopora rossi, Porolithon onkodes and other calcified algae (Reymond et al., 2013; Johnson \& Carpenter, 2018).

Furthermore, human pollution, agricultural production and atmospheric deposition 
have dramatically increased since 1970 s, resulting in excessive nutrients input to coastal seawater (Smith et al., 2003; Felipe van der Struijk \& Kroeze, 2010; Strokal et al., 2014; Brockmann et al., 2018; Murray et al., 2019). This process leads to another environmental issue known as eutrophication (Smith et al., 2003). Several studies showed that water quality slightly recovered from previous eutrophic state in the Baltic Sea, Chesapeake Bay and other coastal seas (Okino \& Kato, 1987; Andersen et al., 2017; McCrackin et al., 2017; Duarte \& Krause-Jensen, 2018). In contrast, severe eutrophic areas are still located at some key bays in China, including Liaodong Bay, Yangtze River Estuary and other jurisdictional seas (MEE, 2019). With exceeded nutrients supply, eutrophication can enhance the growth of phytoplankton, fast-growing filamentous and mat-forming opportunistic macroalgae (Pedersen \& Borum, 1997; Wernberg et al., 2018). Degraded water quality from eutrophication is critical for the development, persistence and expansion of harmful algae blooms (HABs) (Heisler et al., 2008). Recent reports showed that microalgal blooms, Ulva-dominated green tides and Sargassum-dominated golden tides have substantially increased worldwide (Glibert et al., 2005; Smetacek \& Zingone, 2013; Kudela et al., 2015; Wang et al., 2018). HAB resulted from eutrophication affects substance circulation, primary productivity, community structure and marine ecosystem service (Norkko \& Bonsdorff, 1996a,b; Glibert et al., 2005; Rabouille et al., 2008; Heisler et al., 2008; Smetacek \& Zingone, 2013; Anderson et al., 2015; Kudela et al., 2015; Watson et al., 2015).

Several studies have found that coral reef systems are negatively affected by OA and nutrient enrichment (Hoegh-Guldberg et al., 2007; Ge et al., 2017; Guan et al., 2020). For phytoplankton, marine diazotrophs such as Trichodesmium spp. increase their $\mathrm{N}_{2}$ fixation under elevated $\mathrm{CO}_{2}$ in nitrogen enriched cultures (Eichner, Rost \& Kranz, 2014; Hutchins \& Fu, 2017). However, limited investigations aimed to reveal the ecophysiological effects of $\mathrm{OA}$ and eutrophication on marine macrophytes. Previous studies indicated that the growth and quality of $S$. japonica were inhibited and threatened by the interactive effects of OA and eutrophication. (Chu et al., 2019, 
2020). In contrast, there was an enhanced production of amino acid and fatty acid in Ulva species at elevated $\mathrm{CO}_{2}$ concentration and nutrient level (Gao et al., 2018). Thus, the responses to the synergistic stress of OA and eutrophication are species-specific in macroalgae. The rise of acidity in coastal ocean was found to be greater under eutrophication (Cai et al., 2011). This severe scenario potentially aggravate the disappearance of habitat-forming seaweeds worldwide (Wernberg et al., 2018; Filbee-Dexter \& Wernberg, 2018). It is thus important to understand how macroalgae will response to the future synergistic stress of OA and eutrophication.

The kelp Saccharina japonica is the foremost commercial harvesting alga among northwestern Pacific countries (Kim et al., 2017; Chung, Sondak \& Beardall, 2017). In previous studies, the growth, photosynthesis, and nutrient uptake of $S$. japonica were significantly enhanced under elevated $\mathrm{CO}_{2}$ concentrations (Swanson \& Fox, 2007; Zhang et al., 2020). Also, excess nutrient availability significantly promoted the growth and physiological performance of S. japonica (Gao et al., 2017). On the other hand, the sheet-like macroalgae Sargassum horneri blooms frequently occur in recent years (Liu et al., 2013; Xiao, 2019), whose floating thalli have caused detrimental impacts on S. japonica aquaculture (Xiao, 2019). Many investigations have focused on how environmental factors affect population dynamics and distributions of $S$. horneri in East China Sea and Yellow Sea (Xiao, 2019; Xiao et al., 2020; Choi et al., 2020). However, it remains unclear whether $S$. horneri is more resilient to the synergistic stress of OA and eutrophication than S. japonica.

In the present study, we investigated the synergistic stress of $\mathrm{OA}$ and eutrophication on growth, photosynthesis, respiration, chlorophyll contents, and tissue nitrogen of sporophytes of $S$. japonica and $S$. horneri appearing in the same period. The results are expected to reveal the species-specific ecophysiological responses of $S$. japonica and S. horneri, and determine which alga has greater resilience and interspecific competitive dominance under synergistic stress of $\mathrm{OA}$ and eutrophication. 


\section{Materials and Methods}

\subsection{Algal collection and maintenance}

The sporophytes of $S$. japonica (approximately $80 \mathrm{~cm}$ in average length, $\mathrm{n}=20$ ) and $S$. horneri (approximately $150 \mathrm{~cm}$ in average length, $\mathrm{n}=20$ ) were collected in Rongcheng, Shandong, China $\left(36^{\circ} 07^{\top} \mathrm{N}, 120^{\circ} 19^{\prime} \mathrm{E}\right)$, in December 2019. The $S$. japonica samples were from cultivated populations, with S. horneri twining on, or floating between their rafts. The samples were kept in cold foam boxes filled with seawater and quickly transported to the laboratory within $8 \mathrm{~h}$. Healthy sporophytes were selected and rinsed several times with sterilized seawater to remove the epiphytes and detritus. More than 100 discs $(1.4 \mathrm{~cm}$ in diameter) were punched from the meristem of S. japonica with a cork borer, and more than 100 segments $(4-5 \mathrm{~cm}$ in length) were cut from the apical part of $S$. horneri branches for the subsequent experiments. The discs and segments were maintained separately in plastic tanks containing $3 \mathrm{~L}$ filtered seawater. The seawater was renewed daily during the maintenance. These samples were maintained at an irradiance of $90 \mu \mathrm{mol}$ photons $\cdot \mathrm{m}^{-2} \cdot \mathrm{s}^{-1}$ with a $12 \mathrm{~L}: 12 \mathrm{D}$ photoperiod, and $10 \square$, the seawater temperature of the collection area, for 3 days to reduce the negative effects of excision.

\subsection{Culture experiment}

The culture experiment was conducted over a period of 6 days under combinations two $\mathrm{pCO}_{2}$ levels $(400 \mu \mathrm{atm}$ and $1000 \mu \mathrm{atm})$ and two nutrient levels (non-enriched natural seawater and nutrient-enriched seawater). The nutrient-enriched level was enriched 50\% PESI medium (Tatewaki, 1966), which was made by sterilized seawater from coastal Qingdao. There was a total of 4 experimental treatments and each had 3 replicates. Four individuals were cultured in each of 12 gently aerated side-arm flasks, in which each contained $500 \mathrm{~mL}$ non-enriched or enriched seawater at $10 \square$. The culture medium was renewed on the third day of the experiment.

\subsection{Carbonate chemistry parameters}


For the treatments under two $p \mathrm{CO}_{2}$ levels, the samples were cultured in two $\mathrm{CO}_{2}$ incubators (GXZ-380C-C02, Jiangnan Instruments Factory, Ningbo, China). The 400 $\mu$ atm was achieved by bubbling ambient air. And the $1000 \mu$ atm was obtained through gas cylinders of the incubator. The $\mathrm{pH}$ value of the medium in each flask was measured by a $\mathrm{pH}$ meter (Orion STAR A211; Thermo Scientific). The salinity was measured by a seawater salimeter (0-100\%o, Aipli). Other indirectly measured carbonate chemistry parameters of all treatments were calculated based on the $\mathrm{pH}$ values, salinity, $p \mathrm{CO}_{2}$ levels, the equilibrium constants $K_{1}$ and $K_{2}$ for carbonic acid dissociation, and $K_{\mathrm{B}}$ for boric acid, using CO2SYS software (Robbins \& Kleypas, 2018).

\subsection{Measurement of growth}

The growth of S. japonica and S. horneri was determined by weighing fresh weight $(\mathrm{FW})$ of discs or thalli. The discs and thalli were gently scrubbed with tissue paper to remove water from the surface before being weighed. The relative growth rate (RGR) was calculated as the following formula:

\section{$\operatorname{RGR}\left(\%\right.$ day $\left.^{-1}\right)=\left(\ln W_{t}-\ln W_{0}\right) / t \times 100 \%$}

where $t$ is the time period of culture experiment, $W_{0}$ is the initial $F W, W_{t}$ is the FW after $t$ days of culture.

\subsection{Measurement of photosynthesis and respiration}

The net photosynthetic rate $\left(\mathrm{P}_{n}\right)$ and the respiration rate $\left(\mathrm{R}_{\mathrm{d}}\right)$ of the samples was measured by a manual oxygen meter (FireSting $\mathrm{O}_{2} \square$, Pyro Science). After measuring the FW, four discs or segments of each replicates were transferred to the oxygen electrode cuvette with $330 \mathrm{~mL}$ culture medium from their own flasks. The medium was magnetically stirred during the measurement to ensure the even diffusion of oxygen. The irradiance and temperature conditions were set the same as the growth chambers. The samples were set to acclimate to the conditions in the cuvette for $5 \mathrm{~min}$ 
before the measurements. The oxygen concentration in the medium was recorded per minute for $10 \mathrm{~min}$. The increase of oxygen content in the medium within 5 min was defined as the $\mathrm{P}_{\mathrm{n}}$, and the decrease of oxygen content in darkness in the following 5 min was defined as $R_{d}$. The $P_{n}$ and $R_{d}$ were presented as $\mu$ mol $O_{2} \cdot m^{-1} \cdot g^{-1} F W$.

\subsection{Measurement of chlorophyll contents}

Approximately $0.2 \mathrm{~g}(\mathrm{FW})$ of the samples from every replicate were used for the extraction of photosynthetic pigments. The discs or segments were dipped in $2 \mathrm{~mL}$ dimethyl sulfoxide for $5 \mathrm{~min}$, and the absorbance of supernatant was determined at $665,631,582$, and $480 \mathrm{~nm}$ in the ultraviolet absorbance spectrophotometer (U-2900, HITACHI, Tokyo, Japan). Then the same samples were added $3 \mathrm{~mL}$ acetone, setting for $2 \mathrm{~h}$. Before the measurements, $1 \mathrm{~mL}$ methanol and $1 \mathrm{~mL}$ distilled water was added to the supernatant. The absorbance was obtained at $664,631,581$, and $470 \mathrm{~nm}$. The contents of chlorophyll (Chl) $a$ and $c$ were calculated according to the following equation:

$$
\begin{aligned}
& \text { Chl } a\left(\mathrm{mg} \cdot \mathrm{g}^{-1}\right)=\frac{A_{669}}{72.8} \times \mathrm{V}_{1}+\left(\frac{A_{664}}{73.6} \times \mathrm{V}_{0}\right) /(\mathrm{I} \times \mathrm{W})
\end{aligned}
$$

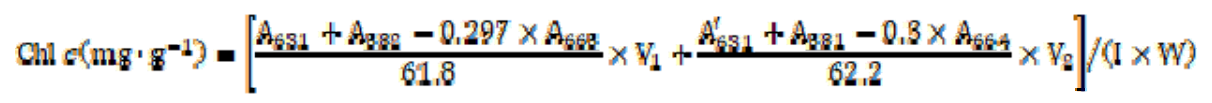

where $A_{665}, A_{664}, A_{582}$ and $A_{581}$ represent the absorbance at $665,664,582$ and

$581 \mathrm{~nm}, \mathrm{~A}_{631}$ is the first absorbance at $631 \mathrm{~nm}, \mathrm{~A}_{631}^{\prime}$ is the second absorbance at $631 \mathrm{~nm}, V_{1}$ is the volume of the first extract, $V_{2}$ is the volume of the second extract, I is the optical path length, and W is the FW of measured samples.

\subsection{Measurement of tissue nitrogen}

One disc or segment was randomly selected from every replicate for the measurement of tissue nitrogen (TN) contents. The samples were completely dried at $80 \square$, and ground into powder. About 2-3 mg powder was used to measure the TN 
contents in the elemental analyzer (Vario EL $\square$, Elementar, Germany). The TN contents were normalized to \%DW.

\subsection{Data analysis}

Results were expressed as mean \pm standard deviation $(n=3)$. Prior to the analysis, the data were conformed to a normal distribution (Shapiro-Wilk test, $P>0.05$ ) and homogeneity of variance (Levene's test, $P>0.05$ ). Two-way analysis of variance (ANOVA) was conducted to assess the combined effects of $p \mathrm{CO}_{2}$ and nutrient levels on carbonate chemistry parameters, RGR, $\mathrm{P}_{\mathrm{n}}, \mathrm{R}_{\mathrm{d}}, \mathrm{Chl} a$, Chl $c$, and TN. Tukey honest significance difference (HSD) was conducted to determine the significance levels of factors $(P<0.05)$. Pearson correlation coefficient (PCCs) was conducted to analyze the correlations of each experimental indicator with $p \mathrm{CO}_{2}$ and nutrients levels $(P$ $<0.05)$. Data were analyzed in SPSS 22.0 software.

\section{Results}

\subsection{Carbonate chemistry parameters of culture medium}

At the same $p \mathrm{CO}_{2}$ level, two-way ANOVA showed that nutrients had no significant effects on any parameter (Table 1). In the culture medium of S. japonica, elevated $p \mathrm{CO}_{2}$ decreased the $\mathrm{pH}$ by 0.3 and $\mathrm{CO}_{3}{ }^{2-}$ by $57 \%$, but it increased the DIC by $12 \%$, $\mathrm{HCO}_{3}{ }^{-}$by $22 \%$, and $\mathrm{CO}_{2}$ by $187 \%$ in both the non-enriched and enriched nutrient treatments. In the culture medium of $S$. horneri, elevated $p \mathrm{CO}_{2}$ decreased the $\mathrm{pH}$ by 0.4 in both nutrient levels and $\mathrm{CO}_{3}{ }^{2-}$ by $75 \%$ (non-enriched) and $65 \%$ (enriched), but it increased the DIC by $27 \%$ (non-enriched) and $4 \%$ (enriched), $\mathrm{HCO}_{3}^{-}$by $13 \%$ (non-enriched) and 5\% (enriched), and $\mathrm{CO}_{2}$ by $191 \%$ in both nutrient treatments.

\subsection{Growth}

The differences in $p \mathrm{CO}_{2}$ and nutrients yielded no significant effects on RGR of $S$. japonica, but nutrients significantly promoted the growth of S. horneri (Fig. 1). At both $400 \mu \mathrm{atm}$ and $1000 \mu \mathrm{atm}$, the RGR of S. japonica decreased due to enriched 
nutrient. In contrast, the RGR of $S$. horneri significantly increased in excessive nutrient availability $(\mathrm{F}=4.550, P<0.05)$. PCCs showed that RGR of $S$. horneri positively correlated with both $\mathrm{pCO}_{2}$ and nutrients. In contrast, RGR of S. japonica positively correlated with $p \mathrm{CO}_{2}$, but negatively correlated with nutrients (Table 4). Together, S. horneri showed more promotive growth under the synergistic stress.

\subsection{Photosynthesis and respiration}

As shown in Fig. 2, nutrient enrichment significantly increased the $\mathrm{P}_{\mathrm{n}}$ of $S$. japonica at both $\mathrm{CO}_{2}$ concentrations $(\mathrm{F}=5.885, P<0.05)$. While no significant effect was detected in S. horneri, $\mathrm{P}_{\mathrm{n}}$ was lower in nutrient-enriched condition. PCCs showed that $\mathrm{P}_{\mathrm{n}}$ in $S$. japonica had positive correlations with $p \mathrm{CO}_{2}$ and nutrients. While $S$. horneri positively correlated with $p \mathrm{CO}_{2}$, but negatively correlated with nutrients (Table 4). Photosynthesis of S. horneri was greater than that of S. japonica at elevated $p \mathrm{CO}_{2}$ and nutrients.

The $\mathrm{R}_{\mathrm{d}}$ in $S$. japonica showed a similar trend to $S$. horneri (Fig. 2). No significant effects on $R_{d}$ of both algae were found in all treatments. At $400 \mu \mathrm{atm}, \mathrm{R}_{\mathrm{d}}$ of both species was lower in excess nutrients. The correlation between $\mathrm{R}_{\mathrm{d}}$ and nutrients of $S$. japonica was positive, but that of $S$. horneri was negative (Table 4). Respiration of $S$. japonica was also greater than that of $S$. horneri under synergistic stress.

\subsection{Chlorophyll contents}

The Chl $a$ and $c$ contents of $S$. japonica significantly increased under either elevated $p \mathrm{CO}_{2}$ or enriched nutrient. Both chlorophyll contents reached the maximum under the synergistic stress (Fig. 3). The Chl a content of S. horneri was significantly increased at enriched nutrients, and also reached the peak in synergistic stress condition. However, the $\mathrm{Chl} c$ content of $S$. horneri increased only with $p \mathrm{CO}_{2}$ elevated. Neither $p \mathrm{CO}_{2}$ nor nutrients significantly affected the Chl $c$ in S. horneri. PCCs showed positive correlations between $\mathrm{Chl} a$ with $p \mathrm{CO}_{2}$ and nutrients in both species. However, correlation between $\mathrm{Chl} c$ and nutrients was significantly negative in $S$. 
horneri (Table 4).

\subsection{Tissue nitrogen}

The TN contents of $S$. japonica and $S$. horneri significantly increased in nutrient-enriched condition (Fig. 4). Elevated $p \mathrm{CO}_{2}$ had no significant effect on the TN of S. japonica, but significantly promoted the accumulation of TN in S. horneri. The correlations between nutrients and $\mathrm{TN}$ were significantly positive in the two species. As for the correlations between $p \mathrm{CO}_{2}$ and $\mathrm{TN}$, it was negative in $S$. japonica but positive in S. horneri (Table 4).

\section{Discussion}

There was a same increase pattern of DIC in the culture medium of $S$. japonica under two nutrient concentrations, but different case was found in the culture medium of $S$. horneri (Table 1). The effects of the synergistic stress of OA and eutrophication on algae may depend on their precise carbon acquisition pathways utilized. The $\mathrm{HCO}_{3}{ }^{-}$in the culture medium of $S$. horneri was lower in enriched nutrient than in non-enriched treatments, indicating more $\mathrm{HCO}_{3}{ }^{-}$utilization paralleled with enriched nutrients. Many macroalgae use $\mathrm{HCO}_{3}{ }^{-}$rather than dissolved $\mathrm{CO}_{2}$ under current seawater $p \mathrm{CO}_{2}$ concentration (Israel \& Hophy, 2002; Badger, 2003; Koch et al., 2013), due to their ribulose-1,5-bisphosphate carboxylase/ oxygenase (Rubisco) is not substrate-saturated at current atmospheric $\mathrm{CO}_{2}$ level (Reiskind, Seamon \& Bowes, 1988). Marine macroalgae have species-specific responses to elevated $\mathrm{CO}_{2}$ because of their various capacities and strategies in $\mathrm{CO}_{2}$-concentrating mechanisms (CCMs) to utilize $\mathrm{HCO}_{3}{ }^{-}$in seawater (Wu, Zou \& Gao, 2008; Raven \& Hurd, 2012). Furthermore, DIC acquisition interacts with phosphorus and nitrogen availability (Giordano, Beardall \& Raven, 2005), but it remains unclear how S. horneri regulates CCMs under excessive nutrient supply. The results indicate that enrichment of nutrients contributed $S$. horneri to the utilization of $\mathrm{HCO}_{3}{ }^{-}$. When exposed to elevated $p \mathrm{CO}_{2}$, macroalgae may reduce the use of $\mathrm{HCO}_{3}{ }^{-}$by down-regulating their CCMs, and begin 
to rely on $\mathrm{CO}_{2}$ as the primary carbon source (Bjork et al., 1993; Axelsson, Mercado \& Figueroa, 2000; Cornwall et al., 2012). This physiological process may have occurred in $S$. japonica, thus leading to the DIC of culture medium remained at the same level after increasing $p \mathrm{CO}_{2}$ under the two nutrient conditions. In contrast, this study provides an evidence that eutrophication restrains the shift of carbon acquisition pathway in $S$. horneri to cope with higher $\mathrm{CO}_{2}$ concentration.

In this study, promotions in RGR were detected in both S. japonica and S. horneri at elevated $p \mathrm{CO}_{2}$ although the increases were statistically non-significant. This indicates that both $S$. japonica and $S$. horneri are capable of OA resistance with atmospheric $\mathrm{CO}_{2}$ increased to $1000 \mu \mathrm{atm}$. To show which algae is competitively dominant under OA condition, we analyzed the $\mathrm{P}_{\mathrm{n}}, \mathrm{R}_{\mathrm{d}}, \mathrm{Chl} a$, Chl $c$ and $\mathrm{TN}$ in both species. The results showed that enhancements to $P_{n}, R_{d}$, and chlorophyll contents of $S$. japonica were parallel with $p \mathrm{CO}_{2}$ elevation. These results are in line with previous investigations on S. japonica (Swanson \& Fox, 2007; Zhang et al., 2020). The enhancement of $\mathrm{P}_{\mathrm{n}}$ and chlorophyll contents were also found in other marine macrophytes, including Gracilariopsis lemaneiformis, Pyropia yezoensis and Ulva prolifera (Kang et al., 2017; Li et al., 2018; Bao et al., 2019). However, the $\mathrm{P}_{\mathrm{n}}$ and chlorophyll contents of $S$. horneri are twice as high as those of $S$. japonica. $S$. horneri increased the utilization of $\mathrm{HCO}_{3}{ }^{-}$to maintain its photosynthesis at a higher level. Since $\mathrm{P}_{\mathrm{n}}$ and $\mathrm{Chl} c$ of $S$. horneri also increased at $1000 \mu$ atm (Fig. 2B, Fig. 3D), photosynthesis of S. horneri was further improved on the basis of the original high level. These results indicate that higher photosynthetic level insured S. horneri potentially greater resilience to $\mathrm{OA}$ in comparison to $S$. japonica.

The significant enhancement in growth was observed in $S$. horneri in nutrient-enriched condition, while no promotion of growth was found in S. japonica (Fig.1). In this study, the concentrations of dissolved inorganic nitrate and ammonium were simultaneously increased in nutrient-enriched treatments (Tatewaki, 1966). Increase in nitrogen availability can enhance macroalgae in $\mathrm{N}$ uptake rates, tissue $\mathrm{N}$ contents, and photosynthetic rates (Valiela et al., 1997). These 
enhancements accelerate the growth of macroalgae. The significant increase in Chl $a$ and TN contents were detected in both species in nutrient-enriched treatments (Fig.3, Fig.4). Previous studies have also determined the same positive physiological responses in Fucus vesiculosus, G. lemaneiformis, Hizikia fusiformis and other macroalgae (Valiela et al., 1997; Kawamitsu \& Boyer, 1999; Wu, Zou \& Gao, 2008; Raven \& Hurd, 2012; Ohlsson et al., 2020). The kinetics of nutrients uptake in macroalgae is affected by the physiological status and the form of nutrients (Raven \& Hurd, 2012; Gao et al., 2017). It has been reported that S. japonica utilize ammonium first when ammonium and nitrate both exist (Wang et al., 2013), while $S$. horneri firstly takes advantage of nitrate (Yu et al., 2019). We estimated according to the measured ecophysiological traits, because the exact concentrations and formations of nitrogen in culture medium were unclear. S. horneri performed higher $\mathrm{P}_{\mathrm{n}}$, more chlorophyll and $\mathrm{TN}$ accumulations under nutrient-enriched condition. Thus, the eutrophic treatment in this study more significantly benefited S. horneri, indicating the increased risk of Sargassum-dominated golden tide in eutrophic condition.

The current study argued the responses of both $S$. japonica and $S$. horneri under synergistic stress of OA and eutrophication. Significant enhancement in chlorophyll and TN contents was observed in both species (Fig. 3, Fig.4). These results indicated that both $S$. japonica and S. horneri improved carbon and nitrogen assimilation. The exceeding nutrient availability in eutrophic scenario regulates these physiological responses in macroalgae to hence the negative effects resulting from declining $\mathrm{pH}$ in OA (Young \& Gobler, 2016; Chu et al., 2020). However, significant increase in growth was only observed on $S$. horneri (Fig. 1). Increased carbon and nitrogen assimilation in $S$. horneri enhanced its growth more than S. japonica. These advantages in ecophyisiological traits may allow $S$. horneri remain dominant and cause damage to S. japonica cultivation in future acidified and eutrophic ocean. Furthermore, the damage resulting from golden tide to $S$. japonica cultivation is likely to be more severe in reality. S.horneri has vesicles in structure, which can keep 
the thalli floating and increase carbon acquisition (Smetacek \& Zingone, 2013; Choi

et al., 2020). Floating S. horneri wrap the rafts, shading the cultivated S. japonica below (Xiao, 2019; Wu et al., 2019). Thus, we suppose that increasing S. horneri biomass shaded cultivated $S$. japonica in a more severe environment with lower light intensity and less carbon availability (Xiao, 2019). The Sargassum-dominated golden tide may cause greater damage to $S$. japonica cultivation in acidified and eutrophic ocean. In addition, we need meso-scale experiments to estimate the increasing risk of golden tide in $S$. japonica cultivation.

\section{Conclusions}

It is important to estimate the damage to $S$. japonica cultivation by golden tide resulting from S. horneri under the synergistic stress of OA and eutrophication. In this study, we determined that nutrient enrichment contributed S. horneri to utilize $\mathrm{HCO}_{3}{ }^{-}$. S. horneri exhibited better photosynthetic traits than S. japonica, and tissue nitrogen also accumulated more in thalli of $S$. horneri in elevated $p \mathrm{CO}_{2}$ and nutrient-enriched treatments. Furthermore, increased carbon and nitrogen assimilation enhanced the growth of S. horneri in acidified and eutrophic scenario. Together, S. horneri may cause greater damage to $S$. japonica cultivation in acidified and eutrophic ocean.

\section{Acknowledgements}

We sincerely thank Zhu Dasheng, from Shandong Lidao Oceanic Technology Company Limited, for his help in providing algal materials for the experiment. This work is funded by Major Scientific and Technological Innovation Project of Shandong Provincial Key Research and Development Program (2019JZZY020708).

\section{References}

Andersen JH, Carstensen J, Conley DJ, Dromph K, Fleming-Lehtinen V, Gustafsson BG, Josefson AB, Norkko A, Villnäs A, Murray C. 2017. Long-term temporal and spatial trends in eutrophication status of the Baltic Sea. Biological Reviews 92:135-149. DOI: 10.1111/brv.12221. 
Anderson CR, Moore SK, Tomlinson MC, Silke J, Cusack CK. 2015. Living with Harmful Algal

Blooms in a Changing World: Strategies for Modeling and Mitigating Their Effects in Coastal

Marine Ecosystems. In: Coastal and Marine Hazards, Risks, and Disasters. Elsevier Inc.,

495-561. DOI: 10.1016/B978-0-12-396483-0.00017-0.

AOAN. 2019. Global Monitoring Laboratory - Carbon Cycle Greenhouse Gases. US Department of Commerce, NOAA, Global Monitoring Laboratory.

Axelsson L, Mercado J, Figueroa F. 2000. Utilization of $\mathrm{HCO}_{3}{ }^{-}$at high $\mathrm{pH}$ by the brown macroalga Laminaria saccharina. European Journal of Phycology 35:53-59. DOI:

$10.1080 / 09670260010001735621$.

Badger M. 2003. The roles of carbonic anhydrases in photosynthetic $\mathrm{CO}_{2}$ concentrating mechanisms.

Photosynthesis Research 77:83-94. DOI: 10.1023/A:1025821717773.

Bao M, Wang J, Xu T, Wu H, Li X, Xu J. 2019. Rising $\mathrm{CO}_{2}$ levels alter the responses of the red macroalga Pyropia yezoensis under light stress. Aquaculture 501:325-330. DOI:

10.1016/j.aquaculture.2018.11.011.

Bjork M, Haglund K, Ramazanov Z, Pedersen M. 1993. Inducible mechanisms for $\mathrm{HCO}_{3}{ }^{-}$utilization and repression of photorespiration in protoplasts and thalli of three species of Ulva (Chlorophyta). Journal of Phycology 29:166-173. DOI: 10.1111/j.0022-3646.1993.00166.x.

Britton D, Cornwall CE, Revill AT, Hurd CL, Johnson CR. 2016. Ocean acidification reverses the positive effects of seawater $\mathrm{pH}$ fluctuations on growth and photosynthesis of the habitat-forming kelp, Ecklonia radiata. Scientific Reports 6. DOI: 10.1038/srep26036.

Brockmann U, Topcu D, Schütt M, Leujak W. 2018. Eutrophication assessment in the transit area German Bight (North Sea) 2006-2014 - Stagnation and limitations. Marine Pollution Bulletin 136:68-78. DOI: 10.1016/j.marpolbul.2018.08.060.

Cai WJ, Hu X, Huang WJ, Murrell MC, Lehrter JC, Lohrenz SE, Chou WC, Zhai W, Hollibaugh JT, Wang Y, Zhao P, Guo X, Gundersen K, Dai M, Gong GC. 2011. Acidification of subsurface coastal waters enhanced by eutrophication. Nature Geoscience 4:766-770. DOI:

10.1038/ngeo1297.

Choi SK, Oh HJ, Yun SH, Lee HJ, Lee K, Han YS, Kim S, Park SR. 2020. Population dynamics of the "golden tides" seaweed, Sargassum horneri, on the southwestern coast of Korea: The extent and 
formation of golden tides. Sustainability (Switzerland) 12. DOI: 10.3390/su12072903.

Chu Y, Liu Y, Li J, Gong Q. 2019. Effects of elevated $p \mathrm{CO}_{2}$ and nutrient enrichment on the growth,

photosynthesis, and biochemical compositions of the brown alga Saccharina japonica

(Laminariaceae, Phaeophyta). PeerJ 2019:e8040. DOI: 10.7717/peerj.8040.

Chu Y, Liu Y, Li J, Wang Q, Gong Q. 2020. Nutrient Enrichment Regulates the Growth and Physiological Responses of Saccharina japonica to Ocean Acidification. Journal of Ocean University of China 19:895-901. DOI: 10.1007/s11802-020-4359-7.

Chung IK, Sondak CFA, Beardall J. 2017. The future of seaweed aquaculture in a rapidly changing world. European Journal of Phycology 52:495-505. DOI: 10.1080/09670262.2017.1359678.

Cornwall CE, Hepburn CD, Pritchard D, Currie KI, Mcgraw CM, Hunter KA, Hurd CL. 2012.

Carbon-use strategies in macroalgae: Differential responses to lowered $\mathrm{pH}$ and implications for ocean acidification. Journal of Phycology 48:137-144. DOI: 10.1111/j.1529-8817.2011.01085.x.

Doney SC, Fabry VJ, Feely RA, Kleypas JA. 2009. Ocean acidification: The other $\mathrm{CO}_{2}$ problem.

Annual Review of Marine Science 1:169-192. DOI: 10.1146/annurev.marine.010908.163834.

Duarte CM, Krause-Jensen D. 2018. Intervention Options to Accelerate Ecosystem Recovery From

Coastal Eutrophication. Frontiers in Marine Science 5:470. DOI: 10.3389/fmars.2018.00470.

Edmunds PJ. 2011. Zooplanktivory ameliorates the effects of ocean acidification on the reef coral

Porites spp. Limnology and Oceanography 56:2402-2410. DOI: 10.4319/lo.2011.56.6.2402.

Eichner M, Rost B, Kranz SA. 2014. Diversity of ocean acidification effects on marine $\mathrm{N}_{2}$ fixers.

Journal of Experimental Marine Biology and Ecology 457:199-207. DOI:

10.1016/j.jembe.2014.04.015.

Enochs IC, Manzello DP, Donham EM, Kolodziej G, Okano R, Johnston L, Young C, Iguel J, Edwards

CB, Fox MD, Valentino L, Johnson S, Benavente D, Clark SJ, Carlton R, Burton T, Eynaud Y, Price NN. 2015. Shift from coral to macroalgae dominance on a volcanically acidified reef.

Nature Climate Change 5:1083-1088. DOI: 10.1038/nclimate2758.

Feely R, Doney S, Cooley S. 2009. Ocean Acidification: Present Conditions and Future Changes in a High- $\mathrm{CO}_{2}$ World. Oceanography 22:36-47. DOI: 10.5670/oceanog.2009.95.

Feely RA, Orr J, Fabry VJ, Kleypas JA, Sabine CL, Langdon C. 2009. Present and future changes in seawater chemistry due to ocean acidification. In: Geophysical Monograph Series. American 
Geophysical Union, 175-188. DOI: 10.1029/2005GM000337.

Feely RA, Sabine CL, Lee K, Berelson W, Kleypas J, Fabry VJ, Millero FJ. 2004. Impact of anthropogenic $\mathrm{CO}_{2}$ on the $\mathrm{CaCO}_{3}$ system in the oceans. Science 305:362-366. DOI: 10.1126/science. 1097329 .

Felipe van der Struijk L, Kroeze C. 2010. Future trends in nutrient export to the coastal waters of South America: Implications for occurrence of eutrophication. Global Biogeochemical Cycles 24:1-14. DOI: $10.1029 / 2009$ GB003572.

Filbee-Dexter K, Wernberg T. 2018. Rise of Turfs: A New Battlefront for Globally Declining Kelp Forests. BioScience 68:64-76. DOI: 10.1093/biosci/bix147.

Gao K, Beardall J, Häder DP, Hall-Spencer JM, Gao G, Hutchins DA. 2019. Effects of ocean acidification on marine photosynthetic organisms under the concurrent influences of warming, UV radiation, and deoxygenation. Frontiers in Marine Science 6:322. DOI: 10.3389/fmars.2019.00322.

Gao G, Clare AS, Chatzidimitriou E, Rose C, Caldwell G. 2018. Effects of ocean warming and acidification, combined with nutrient enrichment, on chemical composition and functional properties of Ulva rigida. Food Chemistry 258:71-78. DOI: 10.1016/j.foodchem.2018.03.040.

Gao X, Endo H, Nagaki M, Agatsuma Y. 2017. Interactive effects of nutrient availability and temperature on growth and survival of different size classes of Saccharina japonica (Laminariales, Phaeophyceae). Phycologia 56:253-260. DOI: 10.2216/16-91.1.

Gazeau F, Quiblier C, Jansen JM, Gattuso JP, Middelburg JJ, Heip CHR. 2007. Impact of elevated CO 2 on shellfish calcification. Geophysical Research Letters 34. DOI: 10.1029/2006GL028554.

Ge C, Chai Y, Wang H, Kan M. 2017. Ocean acidification: One potential driver of phosphorus eutrophication. Marine Pollution Bulletin 115:149-153. DOI: 10.1016/j.marpolbul.2016.12.016.

Giordano M, Beardall J, Raven JA. 2005. $\mathrm{CO}_{2}$ concentrating mechanisms in algae: Mechanisms, environmental modulation, and evolution. Annual Review of Plant Biology 56:99-131. DOI: 10.1146/annurev.arplant.56.032604.144052.

Glibert P, Anderson D, Gentien P, Granéli E, Sellner K. 2005. The Global, Complex Phenomena of Harmful Algal Blooms. Oceanography 18:136-147. DOI: 10.5670/oceanog.2005.49.

Guan Y, Hohn S, Wild C, Merico A. 2020. Vulnerability of global coral reef habitat suitability to ocean 
warming, acidification and eutrophication. Global Change Biology 26:5646-5660. DOI:

$10.1111 /$ gcb. 15293.

Heisler J, Glibert PM, Burkholder JM, Anderson DM, Cochlan W, Dennison WC, Dortch Q, Gobler CJ, Heil CA, Humphries E, Lewitus A, Magnien R, Marshall HG, Sellner K, Stockwell DA, Stoecker

DK, Suddleson M. 2008. Eutrophication and harmful algal blooms: A scientific consensus.

Harmful Algae 8:3-13. DOI: 10.1016/j.hal.2008.08.006.

Hoegh-Guldberg O, Mumby PJ, Hooten AJ, Steneck RS, Greenfield P, Gomez E, Harvell CD, Sale PF,

Edwards AJ, Caldeira K, Knowlton N, Eakin CM, Iglesias-Prieto R, Muthiga N, Bradbury RH,

Dubi A, Hatziolos ME. 2007. Coral reefs under rapid climate change and ocean acidification.

Science (New York, N.Y.) 318:1737-1742. DOI: 10.1126/science.1152509.

Hurd CL, Beardall J, Comeau S, Cornwall CE, Havenhand JN, Munday PL, Parker LM, Raven JA,

McGraw CM. 2020. Ocean acidification as a multiple driver: How interactions between changing seawater carbonate parameters affect marine life. Marine and Freshwater Research 71:263-274.

DOI: $10.1071 / \mathrm{MF} 19267$.

Hutchins DA, Fu F. 2017. Microorganisms and ocean global change. Nature Microbiology 2. DOI:

10.1038/nmicrobiol.2017.58.

Israel A, Hophy M. 2002. Growth, photosynthetic properties and Rubisco activities and amounts of marine macroalgae grown under current and elevated seawater $\mathrm{CO}_{2}$ concentrations. Global Change Biology 8:831-840. DOI: 10.1046/j.1365-2486.2002.00518.x.

Johnson MD, Carpenter RC. 2018. Nitrogen enrichment offsets direct negative effects of ocean acidification on a reef-building crustose coralline alga. Biology Letters 14. DOI: 10.1098/rsbl.2018.0371.

Joos F, Spahni R. 2008. Rates of change in natural and anthropogenic radiative forcing over the past 20,000 years. Proceedings of the National Academy of Sciences of the United States of America 105:1425-1430. DOI: 10.1073/pnas.0707386105.

Kang JW, Kambey C, Shen Z, Yang Y, Chung IK. 2017. The short-term effects of elevated $\mathrm{CO}_{2}$ and ammonium concentrations on physiological responses in Gracilariopsis lemaneiformis (Rhodophyta). Fisheries and Aquatic Sciences 20. DOI: 10.1186/s41240-017-0063-y.

Kawamitsu Y, Boyer JS. 1999. Photosynthesis and carbon storage between tides in a brown alga, 
Fucus vesiculosus. Marine Biology 133:361-369. DOI: 10.1007/s002270050475.

Kim JK, Yarish C, Hwang EK, Park M, Kim Y. 2017. Seaweed aquaculture: Cultivation technologies, challenges and its ecosystem services. Algae 32:1-13. DOI: 10.4490/algae.2017.32.3.3.

Koch M, Bowes G, Ross C, Zhang XH. 2013. Climate change and ocean acidification effects on seagrasses and marine macroalgae. Global Change Biology 19:103-132. DOI:

10.1111/j.1365-2486.2012.02791.x.

Kroeker KJ, Kordas RL, Crim R, Hendriks IE, Ramajo L, Singh GS, Duarte CM, Gattuso JP. 2013. Impacts of ocean acidification on marine organisms: Quantifying sensitivities and interaction with warming. Global Change Biology 19:1884-1896. DOI: 10.1111/gcb.12179.

Kudela RM, Bickel A, Carter ML, Howard MDA, Rosenfeld L. 2015. The Monitoring of Harmful Algal Blooms through Ocean Observing: The Development of the California Harmful Algal Bloom Monitoring and Alert Program. In: Coastal Ocean Observing Systems. Elsevier Inc., 58-75. DOI: 10.1016/B978-0-12-802022-7.00005-5.

Li Y, Zhong J, Zheng M, Zhuo P, Xu N. 2018. Photoperiod mediates the effects of elevated $\mathrm{CO}_{2}$ on the growth and physiological performance in the green tide alga Ulva prolifera. Marine Environmental Research 141:24-29. DOI: 10.1016/j.marenvres.2018.07.015.

Liu D, Keesing JK, He P, Wang Z, Shi Y, Wang Y. 2013. The world's largest macroalgal bloom in the Yellow Sea, China: Formation and implications. Estuarine, Coastal and Shelf Science 129:2-10. DOI: $10.1016 /$ j.ecss.2013.05.021.

McCrackin ML, Jones HP, Jones PC, Moreno-Mateos D. 2017. Recovery of lakes and coastal marine ecosystems from eutrophication: A global meta-analysis. Limnology and Oceanography 62:507-518. DOI: 10.1002/lno.10441.

MEE. 2019. Bulletin of Marine Ecology and Environment Status of China in 2018. Beijing.

Murray CJ, Müller-Karulis B, Carstensen J, Conley DJ, Gustafsson BG, Andersen JH. 2019. Past, Present and Future Eutrophication Status of the Baltic Sea. Frontiers in Marine Science 6:2. DOI: 10.3389/fmars.2019.00002.

Norkko A, Bonsdorff E. 1996a. Rapid zoobenthic community responses to accumulations of drifting algae. Marine Ecology Progress Series 131:143-157. DOI: 10.3354/meps131143.

Norkko A, Bonsdorff E. 1996b. Population responses of coastal zoobenthos to stress induced by 
drifting algal mats. Marine Ecology Progress Series 140:141-151. DOI: 10.3354/meps140141.

Ohlsson LO, Karlsson S, Rupar-Gadd K, Albers E, Welander U. 2020. Evaluation of Laminaria digitata and Phragmites australis for biogas production and nutrient recycling. Biomass and Bioenergy 140:105670. DOI: 10.1016/j.biombioe.2020.105670.

Okino T, Kato K. 1987. Lake Suwa - Eutrophication and its partial recent recovery. GeoJournal 14:373-375. DOI: 10.1007/BF00208212.

Pedersen M, Borum J. 1997. Nutrient control of estuarine macroalgae:growth strategy and the balance between nitrogen requirements and uptake. Marine Ecology Progress Series 161:155-163. DOI: $10.3354 /$ meps 161155 .

Rabouille C, Conley DJ, Dai MH, Cai WJ, Chen CTA, Lansard B, Green R, Yin K, Harrison PJ, Dagg M, McKee B. 2008. Comparison of hypoxia among four river-dominated ocean margins: The Changjiang (Yangtze), Mississippi, Pearl, and Rhône rivers. Continental Shelf Research 28:1527-1537. DOI: 10.1016/j.csr.2008.01.020.

Raven JA, Hurd CL. 2012. Ecophysiology of photosynthesis in macroalgae. In: Photosynthesis Research. Springer, 105-125. DOI: 10.1007/s11120-012-9768-z.

Reiskind JB, Seamon PT, Bowes G. 1988. Alternative Methods of Photosynthetic Carbon Assimilation in Marine Macroalgae. Plant Physiology 87:686-692. DOI: 10.1104/pp.87.3.686.

Reymond CE, Lloyd A, Kline DI, Dove SG, Pandolfi JM. 2013. Decline in growth of foraminifer Marginopora rossi under eutrophication and ocean acidification scenarios. Global Change Biology 19:291-302. DOI: 10.1111/gcb.12035.

Robbins LL, Kleypas J. 2018. $\mathrm{CO}_{2}$ system Calculations.

Shi D, Hong H, Su X, Liao L, Chang S, Lin W. 2019. The physiological response of marine diatoms to ocean acidification: differential roles of seawater $\mathrm{CO}_{2}$ and pH. Journal of Phycology 55:521-533. DOI: $10.1111 /$ jpy.12855.

Shi D, Kranz SA, Kim JM, Morel FMM. 2012. Ocean acidification slows nitrogen fixation and growth in the dominant diazotroph Trichodesmium under low-iron conditions. Proceedings of the National Academy of Sciences of the United States of America 109:E3094-E3100. DOI: 10.1073/pnas.1216012109.

Smetacek V, Zingone A. 2013. Green and golden seaweed tides on the rise. Nature 504:84-88. DOI: 
$10.1038 /$ nature 12860 .

Smith S V., Swaney DP, Talaue-McManus L, Bartley JD, Sandhei PT, McLaughlin CJ, Dupra VC, Crossland CJ, Buddemeier RW, Maxwell BA, Wulff F. 2003. Humans, hydrology, and the distribution of inorganic nutrient loading to the ocean. BioScience 53:235-245. DOI: 10.1641/0006-3568(2003)053[0235:HHATDO]2.0.CO;2.

Strokal M, Yang H, Zhang Y, Kroeze C, Li L, Luan S, Wang H, Yang S, Zhang Y. 2014. Increasing eutrophication in the coastal seas of China from 1970 to 2050. Marine Pollution Bulletin 85:123-140. DOI: 10.1016/j.marpolbul.2014.06.011.

Swanson AK, Fox CH. 2007. Altered kelp (Laminariales) phlorotannins and growth under elevated carbon dioxide and ultraviolet-B treatments can influence associated intertidal food webs. Global Change Biology 13:1696-1709. DOI: 10.1111/j.1365-2486.2007.01384.x.

Tatewaki M. 1966. Formation of a Crustaceous Sporophyte with Unilocular Sporangia in Scytosiphon lomentaria. Phycologia 6:62-66. DOI: 10.2216/10031-8884-6-1-62.1.

Valiela I, McClelland J, Hauxwell J, Behr PJ, Hersh D, Foreman K. 1997. Macroalgal blooms in shallow estuaries: Controls and ecophysiological and ecosystem consequences. Limnology and Oceanography 42:1105-1118. DOI: 10.4319/lo.1997.42.5_part_2.1105.

Wang B, Xin M, Wei Q, Xie L. 2018. A historical overview of coastal eutrophication in the China Seas. Marine Pollution Bulletin 136:394-400. DOI: 10.1016/j.marpolbul.2018.09.044.

Wang Y, Xu D, Fan X, Zhang X, Ye N, Wang W, Mao Y, Mou S, Cao S. 2013. Variation of photosynthetic performance, nutrient uptake, and elemental composition of different generations and different thallus parts of Saccharina japonica. Journal of Applied Phycology 25:631-637. DOI: $10.1007 / \mathrm{s} 10811-012-9897-y$.

Watson SB, Whitton BA, Higgins SN, Paerl HW, Brooks BW, Wehr JD. 2015. Harmful Algal Blooms. In: Freshwater Algae of North America: Ecology and Classification. Elsevier Inc., 873-920. DOI: 10.1016/B978-0-12-385876-4.00020-7.

Wernberg T, Krumhansl K, Filbee-Dexter K, Pedersen MF. 2018. Status and trends for the world's kelp forests. In: World Seas: An Environmental Evaluation Volume III: Ecological Issues and Environmental Impacts. Elsevier, 57-78. DOI: 10.1016/B978-0-12-805052-1.00003-6.

Wu H, Feng J, Li X, Zhao C, Liu Y, Yu J, Xu J. 2019. Effects of increased CO2 and temperature on the 
physiological characteristics of the golden tide blooming macroalgae Sargassum horneri in the

Yellow Sea, China. Marine Pollution Bulletin 146:639-644. DOI:

10.1016/j.marpolbul.2019.07.025.

Wu HY, Zou DH, Gao KS. 2008. Impacts of increased atmospheric $\mathrm{CO}_{2}$ concentration on

photosynthesis and growth of micro- and macro-algae. Science in China, Series C: Life Sciences

51:1144-1150. DOI: 10.1007/s11427-008-0142-5.

Xiao J. 2019. Interim report on progress of drifting Sargassum horneri in Yellow Sea (Genetic diversity of benthic and floating populations of Sargassum in western Yellow Sea).

Xiao J, Wang Z, Song H, Fan S, Yuan C, Fu M, Miao X, Zhang X, Su R, Hu C. 2020. An anomalous bi-macroalgal bloom caused by Ulva and Sargassum seaweeds during spring to summer of 2017 in the western Yellow Sea, China. Harmful Algae 93:101760. DOI: 10.1016/j.hal.2020.101760.

Xu D, Brennan G, Xu L, Zhang XW, Fan X, Han WT, Mock T, McMinn A, Hutchins DA, Ye N. 2019. Ocean acidification increases iodine accumulation in kelp $\square$ based coastal food webs. Global Change Biology 25:629-639. DOI: 10.1111/gcb.14467.

Young CS, Gobler CJ. 2016. Ocean Acidification Accelerates the Growth of Two Bloom-Forming Macroalgae. PLoS ONE 5:e0155152. DOI: 10.1371/journal.pone.0155152.

Yu J, Li J, Wang Q, Liu Y, Gong Q. 2019. Growth and Resource Accumulation of Drifting Sargassum horneri (Fucales, Phaeophyta) in Response to Temperature and Nitrogen Supply. Journal of Ocean University of China 18:1216-1226. DOI: 10.1007/s11802-019-3835-4.

Zhang X, Xu D, Guan Z, Wang S, Zhang Y, Wang W, Zhang X, Fan X, Li F, Ye N. 2020. Elevated $\mathrm{CO}_{2}$ concentrations promote growth and photosynthesis of the brown alga Saccharina japonica. Journal of Applied Phycology 32:1949-1959. DOI: 10.1007/s10811-020-02108-1.

\section{Figure captions}

Fig. 1 Relative growth rate (RGR) of S. japonica (A) and S. horneri (B) cultured at different $p \mathrm{CO}_{2}$ and nutrient conditions for 6 days. Data are reported as means $\pm \mathrm{SD}(\mathrm{n}$ =3). Different letters above the error bars indicate significant differences between 
treatments $(P<0.05)$.

Fig. 2 Net photosynthetic rate $\left(\mathrm{P}_{\mathrm{n}}\right)$ of $S$. japonica (A) and S. horneri (B); Respiration rate $\left(\mathrm{R}_{\mathrm{d}}\right)$ of $S$. japonica $(\mathrm{C})$ and $S$. horneri (D) cultured at different $p \mathrm{CO}_{2}$ and nutrient conditions for 6 days. Data are reported as means \pm SD $(n=3)$. Different letters above the error bars indicate significant differences between treatments $(P<0.05)$.

Fig. $3 \mathrm{Chl} a$ of S. japonica (A) and S. horneri (B); Chl $c$ of S. japonica (C) and $S$. horneri (D) cultured at different $\mathrm{pCO}_{2}$ and nutrient conditions for 6 days. Data are reported as means $\pm \mathrm{SD}(\mathrm{n}=3)$. Different letters above the error bars indicate significant differences between treatments $(P<0.05)$.

Fig. 4 Tissue nitrogen (TN) of S. japonica (A) and S. horneri (B) cultured at different $p \mathrm{CO}_{2}$ and nutrient conditions for 6 days. Data are reported as means $\pm \mathrm{SD}(\mathrm{n}=3)$. Different letters above the error bars indicate significant differences between treatments $(P<0.05)$. 
Table 1 Parameters of the seawater carbonate system at different $p \mathrm{CO}_{2}$ and nutrient conditions.

\begin{tabular}{|c|c|c|c|c|c|c|c|}
\hline Treatments & $\mathrm{pH}$ & $\begin{array}{l}p \mathrm{CO}_{2} \\
\text { ( } \mu \text { atm) }\end{array}$ & $\begin{array}{l}\text { DIC } \\
\left(\mu \mathrm{mol} \cdot \mathrm{kg}^{-1}\right)\end{array}$ & $\begin{array}{l}\mathrm{HCO}_{3}^{-} \\
\left(\mu \mathrm{mol} \cdot \mathrm{kg}^{-1}\right)\end{array}$ & $\begin{array}{l}\mathrm{CO}_{3}{ }^{2-} \\
\left(\mu \mathrm{mol} \cdot \mathrm{kg}^{-1}\right)\end{array}$ & $\begin{array}{l}\mathrm{CO}_{2} \\
\left(\mu \mathrm{mol} \cdot \mathrm{kg}^{-1}\right)\end{array}$ & $\begin{array}{l}\text { TA } \\
\left(\mu \mathrm{mol} \cdot \mathrm{kg}^{-1}\right)\end{array}$ \\
\hline \multicolumn{8}{|l|}{ S. japonica } \\
\hline L-N & $8.42 \pm 0.17^{\mathrm{b}}$ & $360.29 \pm 50.85^{\mathrm{a}}$ & $4352.52 \pm 2604.58^{\mathrm{a}}$ & $3793.34 \pm 2023.28^{\mathrm{a}}$ & $541.47 \pm 583.91^{\mathrm{b}}$ & $17.42 \pm 2.11^{\mathrm{a}}$ & $4978.38 \pm 3210.98^{\mathrm{a}}$ \\
\hline L-E & $8.47 \pm 0.16^{\mathrm{b}}$ & $360.29 \pm 50.85^{\mathrm{a}}$ & $4812.57 \pm 2856.49^{\mathrm{a}}$ & $4140.31 \pm 2145.30^{\mathrm{a}}$ & $654.59 \pm 713.85^{\mathrm{b}}$ & $17.67 \pm 2.50^{\mathrm{a}}$ & $5560.10 \pm 3597.04^{\mathrm{a}}$ \\
\hline $\mathrm{H}-\mathrm{N}$ & $8.09 \pm 0.07^{\mathrm{a}}$ & $1043.43 \pm 46.57^{\mathrm{b}}$ & $4934.55 \pm 656.25^{\mathrm{a}}$ & $4651.80 \pm 598.56^{\mathrm{a}}$ & $230.95 \pm 60.78^{\mathrm{a}}$ & $49.30 \pm 3.73^{b}$ & $5163.78 \pm 722.89^{a}$ \\
\hline H-E & $8.13 \pm 0.05^{\mathrm{a}}$ & $1043.43 \pm 46.57^{b}$ & $5371.04 \pm 637.60^{\mathrm{a}}$ & $5046.65 \pm 581.58^{\mathrm{a}}$ & $272.77 \pm 56.40^{\mathrm{a}}$ & $51.62 \pm 2.19^{\mathrm{b}}$ & $5647.01 \pm 697.17^{\mathrm{a}}$ \\
\hline \multicolumn{8}{|l|}{ S. horneri } \\
\hline L-N & $8.54 \pm 0.13^{b}$ & $360.29 \pm 50.85^{\mathrm{a}}$ & $5324.88 \pm 831.22^{\mathrm{a}}$ & $5006.21 \pm 752.91^{\mathrm{a}}$ & $1077.56 \pm 648.92^{b}$ & $17.79 \pm 2.54^{\mathrm{a}}$ & $7936.41 \pm 3033.63^{\mathrm{a}}$ \\
\hline L-E & $8.57 \pm 0.12^{b}$ & $360.29 \pm 50.85^{\mathrm{a}}$ & $5615.11 \pm 1104.80^{\mathrm{a}}$ & $4997.68 \pm 1705.43^{\mathrm{a}}$ & $834.21 \pm 580.90^{\mathrm{b}}$ & $17.86 \pm 2.58^{\mathrm{a}}$ & $6788.73 \pm 2879.69^{\mathrm{a}}$ \\
\hline $\mathrm{H}-\mathrm{N}$ & $8.13 \pm 0.07^{\mathrm{a}}$ & $1043.43 \pm 46.57^{\mathrm{b}}$ & $6742.56 \pm 2368.32^{\mathrm{a}}$ & $5647.21 \pm 1737.10^{\mathrm{a}}$ & $266.81 \pm 79.61^{\mathrm{a}}$ & $51.85 \pm 2.34^{\mathrm{b}}$ & $5592.57 \pm 916.11^{\mathrm{a}}$ \\
\hline H-E & $8.14 \pm 0.09^{\mathrm{a}}$ & $1043.43 \pm 46.57^{\mathrm{b}}$ & $5849.75 \pm 2281.55^{\mathrm{a}}$ & $5268.89 \pm 1005.26^{\mathrm{a}}$ & $294.21 \pm 99.68^{\mathrm{a}}$ & $52.01 \pm 2.21^{\mathrm{b}}$ & $5910.93 \pm 1211.03^{\mathrm{a}}$ \\
\hline
\end{tabular}

Notes: $\mathrm{L}-\mathrm{N}$ is the low $p \mathrm{CO}_{2}$ and non-enriched condition, $\mathrm{L}-\mathrm{E}$ is the low $p \mathrm{CO}_{2}$ and enriched condition, $\mathrm{H}-\mathrm{N}$ is the high $p \mathrm{CO} 2$ and non-enriched condition, and H-E is the high $p \mathrm{CO}_{2}$ and enriched condition. DIC is dissolved inorganic carbon, and TA is total alkalinity. Data are reported as means $\pm \mathrm{SD}(\mathrm{n}=3)$. Different superscript letters indicate significant differences in one parameter between treatments $(P<0.05)$. 
Table 2 Analysis of variance (two-way ANOVA) examining the statistical differences of experimental parameters of S. japonica among $p \mathrm{CO}_{2}$ and nutrients

\begin{tabular}{|c|c|c|c|}
\hline \multirow[b]{2}{*}{ Factors } & \multicolumn{3}{|c|}{ S. japonica } \\
\hline & $\mathrm{df}$ & $\mathrm{F}$ & $\mathrm{P}$ \\
\hline \multicolumn{4}{|l|}{ RGR } \\
\hline$p \mathrm{CO}_{2}$ & 1 & 0.188 & 0.676 \\
\hline Nutrients & 1 & 0.358 & 0.566 \\
\hline$p \mathrm{CO}_{2} \times$ Nutrients & 1 & 0.115 & 0.743 \\
\hline \multicolumn{4}{|l|}{$\mathrm{P}_{\mathrm{n}}$} \\
\hline$p \mathrm{CO}_{2}$ & 1 & 0.364 & 0.563 \\
\hline Nutrients & 1 & 5.885 & $<0.05$ \\
\hline$p \mathrm{CO}_{2} \times$ Nutrients & 1 & 0.001 & 0.972 \\
\hline \multicolumn{4}{|l|}{$\mathrm{R}_{\mathrm{d}}$} \\
\hline$p \mathrm{CO}_{2}$ & 1 & 1.739 & 0.224 \\
\hline Nutrients & 1 & 0.039 & 0.848 \\
\hline$p \mathrm{CO}_{2} \times$ Nutrients & 1 & 0.450 & 0.521 \\
\hline \multicolumn{4}{|l|}{ Chl $a$} \\
\hline$p \mathrm{CO}_{2}$ & 1 & 13.786 & $<0.01$ \\
\hline Nutrients & 1 & 9.476 & $<0.01$ \\
\hline$p \mathrm{CO}_{2} \times$ Nutrients & 1 & 8.251 & $<0.05$ \\
\hline \multicolumn{4}{|l|}{$\mathrm{Chl} c$} \\
\hline$p \mathrm{CO}_{2}$ & 1 & 0.054 & 0.822 \\
\hline Nutrients & 1 & 9.308 & $<0.05$ \\
\hline$p \mathrm{CO}_{2} \times$ Nutrients & 1 & 0.088 & 0.774 \\
\hline \multicolumn{4}{|l|}{$\mathrm{TN}$} \\
\hline$p \mathrm{CO}_{2}$ & 1 & 0.042 & 0.843 \\
\hline Nutrients & 1 & 158.903 & $<0.001$ \\
\hline$p \mathrm{CO}_{2} \times$ Nutrients & 1 & 0.659 & 0.440 \\
\hline
\end{tabular}


Table 3 Analysis of variance (two-way ANOVA) examining the statistical differences of experimental parameters of S. horneri among $p \mathrm{CO}_{2}$ and nutrients

\begin{tabular}{|c|c|c|c|}
\hline \multirow[b]{2}{*}{ Factors } & \multicolumn{3}{|c|}{ S. horneri } \\
\hline & $\mathrm{df}$ & $\mathrm{F}$ & $\mathrm{P}$ \\
\hline \multicolumn{4}{|l|}{ RGR } \\
\hline$p \mathrm{CO}_{2}$ & 1 & 0.569 & 0.475 \\
\hline Nutrients & 1 & 4.550 & $<0.05$ \\
\hline$p \mathrm{CO}_{2} \times$ Nutrients & 1 & 0.749 & 0.415 \\
\hline \multicolumn{4}{|l|}{$\mathrm{P}_{\mathrm{n}}$} \\
\hline$p \mathrm{CO}_{2}$ & 1 & 0.025 & 0.879 \\
\hline Nutrients & 1 & 0.286 & 0.607 \\
\hline$p \mathrm{CO}_{2} \times$ Nutrients & 1 & 0.279 & 0.612 \\
\hline \multicolumn{4}{|l|}{$\mathrm{R}_{\mathrm{d}}$} \\
\hline$p \mathrm{CO}_{2}$ & 1 & 0.015 & 0.904 \\
\hline Nutrients & 1 & 2.607 & 0.145 \\
\hline$p \mathrm{CO}_{2} \times$ Nutrients & 1 & 0.988 & 0.349 \\
\hline \multicolumn{4}{|l|}{ Chl $a$} \\
\hline$p \mathrm{CO}_{2}$ & 1 & 1.420 & 0.268 \\
\hline Nutrients & 1 & 13.909 & $<0.01$ \\
\hline$p \mathrm{CO}_{2} \times$ Nutrients & 1 & 0.077 & 0.789 \\
\hline \multicolumn{4}{|l|}{$\mathrm{Chl} c$} \\
\hline$p \mathrm{CO}_{2}$ & 1 & 0.592 & 0.463 \\
\hline Nutrients & 1 & 0.740 & 0.414 \\
\hline$p \mathrm{CO}_{2} \times$ Nutrients & 1 & 0.060 & 0.812 \\
\hline \multicolumn{4}{|l|}{$\mathrm{TN}$} \\
\hline$p \mathrm{CO}_{2}$ & 1 & 6.053 & $<0.05$ \\
\hline Nutrients & 1 & 27.868 & $<0.01$ \\
\hline$p \mathrm{CO}_{2} \times$ Nutrients & 1 & 2.147 & 0.181 \\
\hline
\end{tabular}


Table 4 The Pearson correlation coefficient (PCCs) of various experimental indicators of $S$. japonica and $S$. horneri with $p \mathrm{CO}_{2}$ and nutrients levels

\begin{tabular}{lllllll}
\hline Treatments & $\mathrm{RGR}$ & $\mathrm{P}_{\mathrm{n}}$ & $\mathrm{R}_{\mathrm{d}}$ & $\mathrm{Chl} a$ & $\mathrm{Chl} c$ & $\mathrm{TN}$ \\
\hline S. japonica & & & & & & \\
$p \mathrm{CO}_{2}$ & $0.533^{* *}$ & 0.241 & $0.883^{*}$ & 0.359 & 0.380 & -0.016 \\
Nutrients & $-0.736^{* *}$ & $0.970^{* *}$ & $0.133^{*}$ & $0.933^{*}$ & $0.924^{*}$ & $0.998^{* *}$ \\
S. horneri & & & & & & \\
$p \mathrm{CO}_{2}$ & $0.021^{*}$ & $0.030^{*}$ & $0.670^{*}$ & $0.463^{*}$ & $0.953^{* *}$ & 0.410 \\
Nutrients & $0.994^{* *}$ & $-0.961^{* *}$ & $-0.711^{* *}$ & $0.777^{* *}$ & $-0.246^{* *}$ & $0.879^{*}$ \\
\hline
\end{tabular}

Notes: * indicates significant correlation $(P<0.05), * *$ indicates highly significant correlation $(P<0.01)$. 


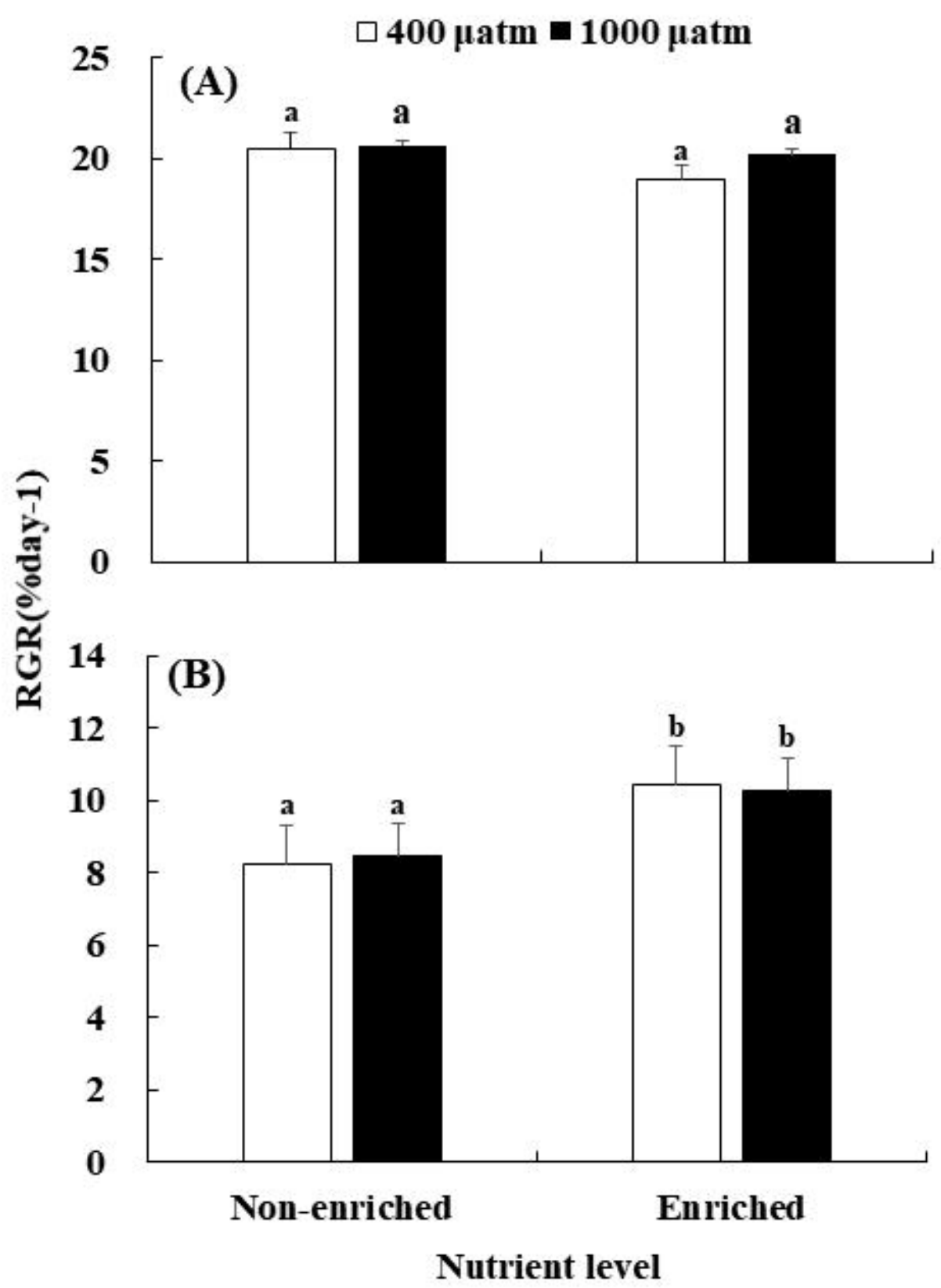

Fig. 1 Relative growth rate (RGR) of S. japonica (A) and S. horneri (B) cultured at different $p \mathrm{CO}_{2}$ and nutrient conditions for 6 days. Data are reported as means $\pm \mathrm{SD}(\mathrm{n}=3)$. Different letters above the error bars indicate significant differences between treatments $(P<0.05)$. 

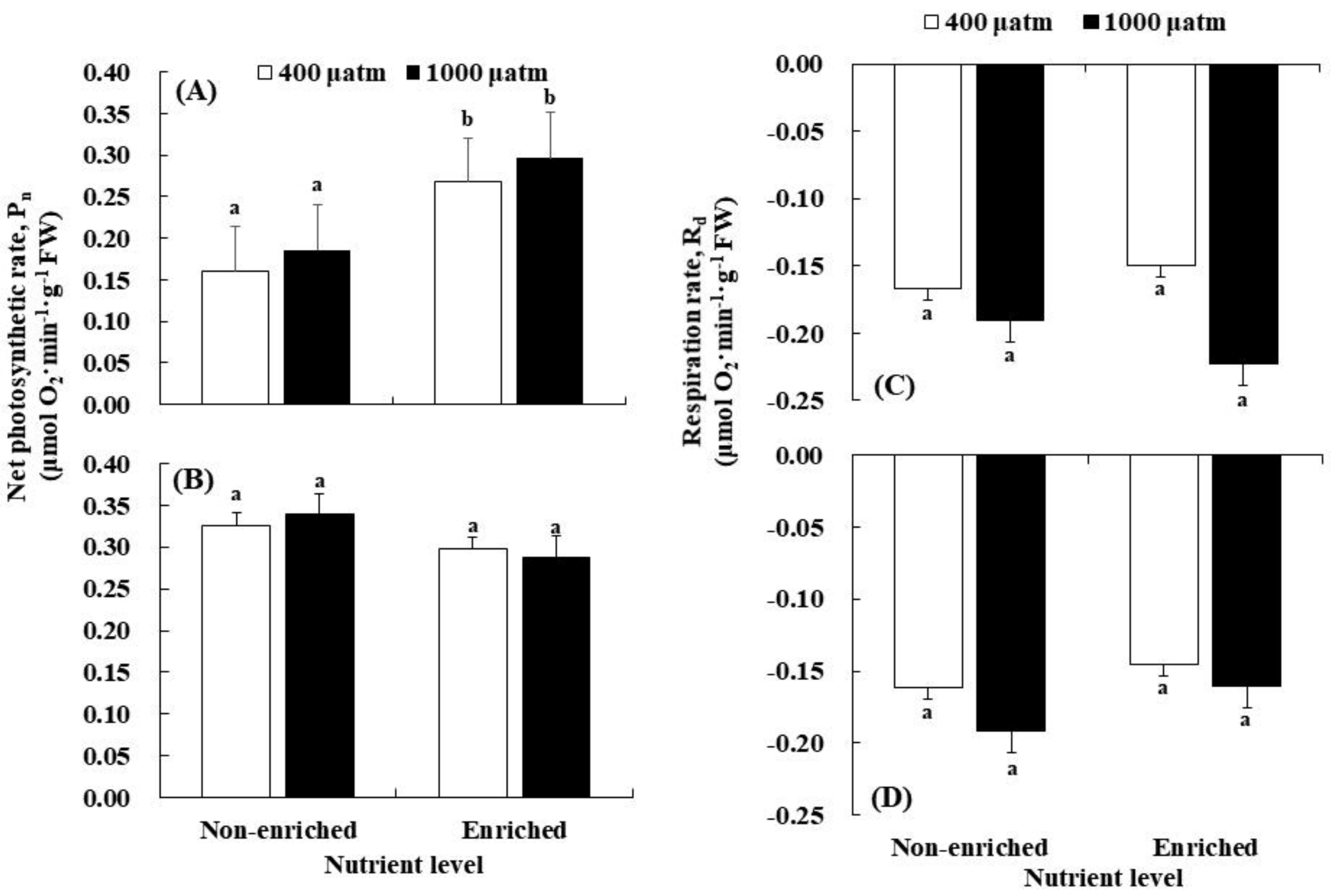

Fig. 2 Net photosynthetic rate $\left(\mathrm{P}_{\mathrm{n}}\right)$ of $S$. japonica (A) and S. horneri (B); Respiration rate $\left(\mathrm{R}_{\mathrm{d}}\right)$ of $S$. japonica (C) and $S$. horneri (D) cultured at different $p \mathrm{CO}_{2}$ and nutrient conditions for 6 days. Data are reported as means $\pm \mathrm{SD}(\mathrm{n}=3)$. Different letters above the error bars indicate significant differences between treatments $(P<0.05)$. 
$\square 400 \mu \mathrm{atm} \square 1000 \mu \mathrm{atm}$

Є0

0.30

(A)

0.25

0.20

0.15

0.10

0.05

0.00

0.60

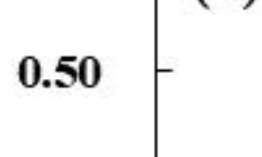

(B)

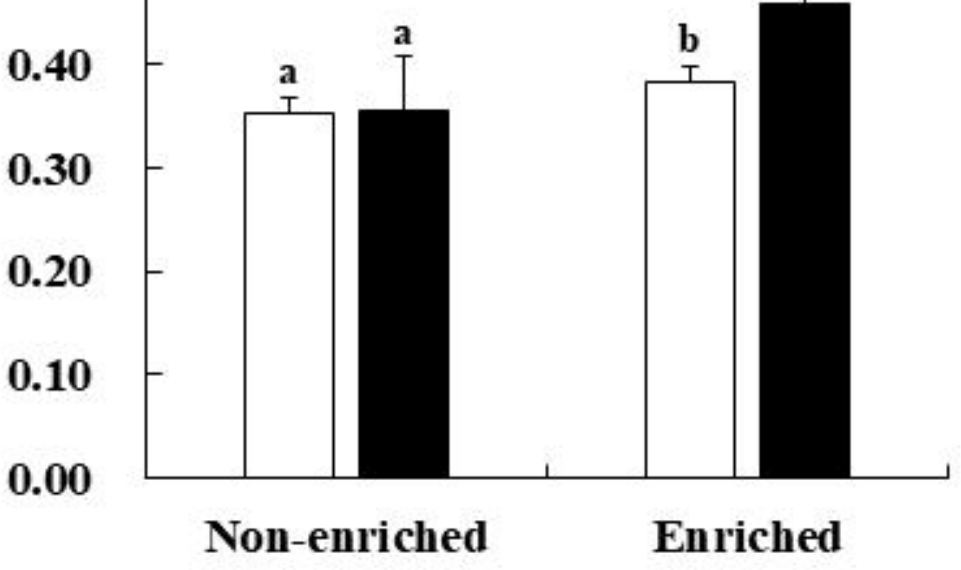

Nutrient level $\square 400 \mu \mathrm{atm} \square 1000 \mu \mathrm{atm}$
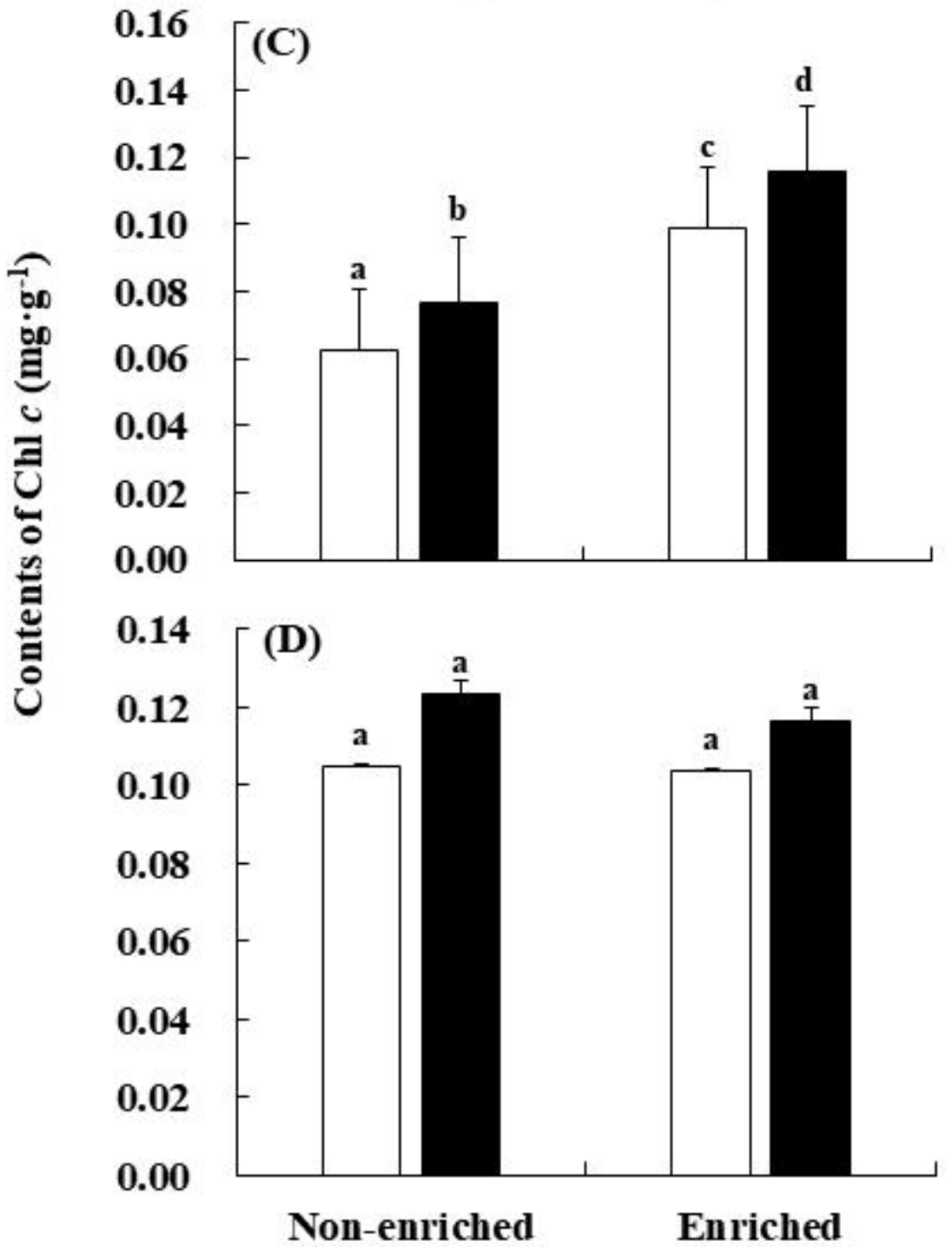

Nutrient level

Fig. $3 \mathrm{Chl} a$ of S. japonica (A) and S. horneri (B); $\mathrm{Chl} c$ of S. japonica (C) and S. horneri (D) cultured at different $p \mathrm{CO}_{2}$ and nutrient conditions for 6 days. Data are reported as means $\pm S D(n=3)$. Different letters above the error bars indicate significant differences between treatments $(P<0.05)$. 


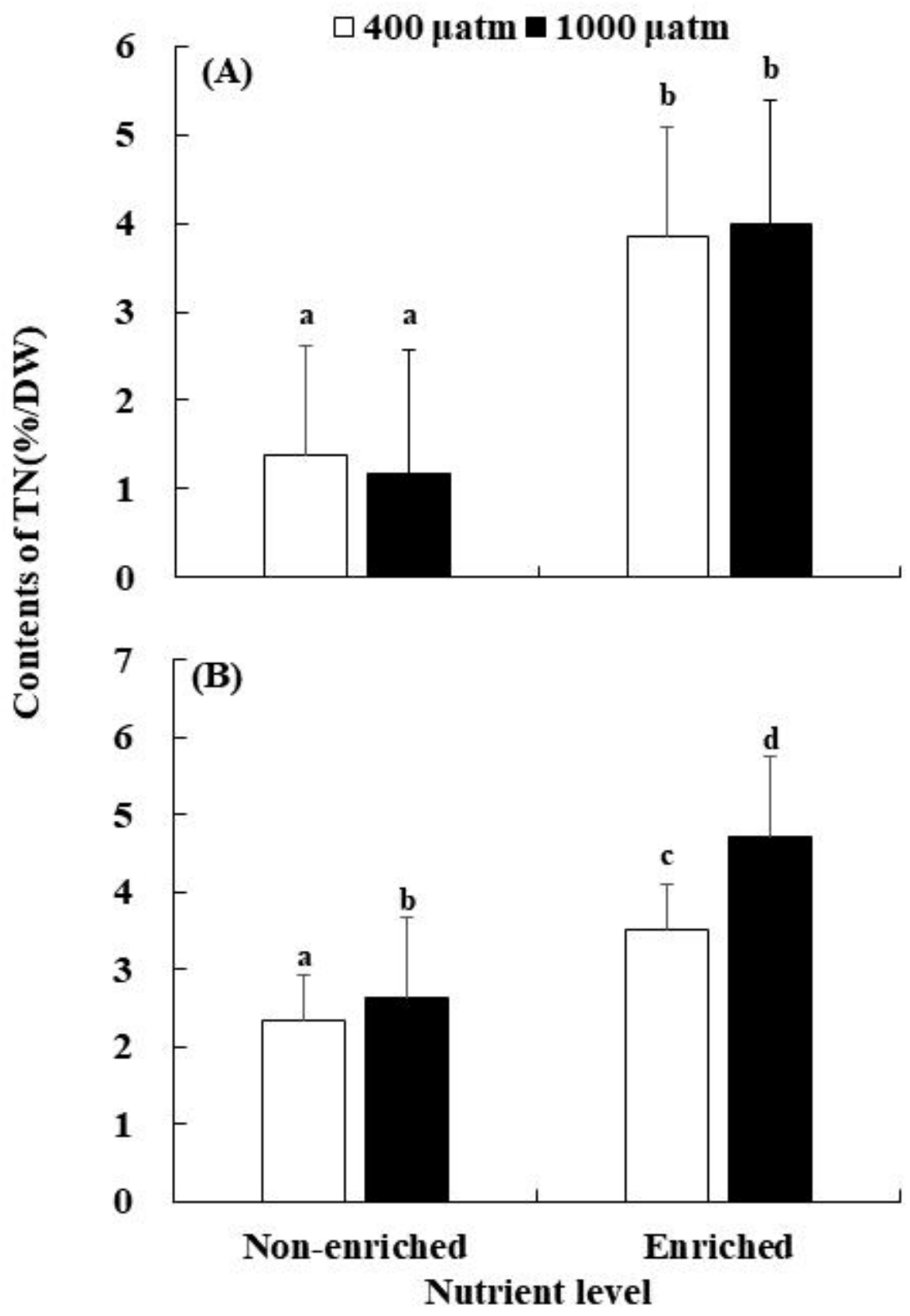

Fig. 4 Tissue nitrogen (TN) of S. japonica (A) and S. horneri (B) cultured at different $p \mathrm{CO}_{2}$ and nutrient conditions for 6 days. Data are reported as means $\pm \mathrm{SD}(\mathrm{n}=3)$. Different letters above the error bars indicate significant differences between treatments $(P<0.05)$. 